4th National Seminar on Guidance and Counseling (SNBK 2019) and Workshop on

Pedagogical Theory and Practice (WTPP 2019)

SHEs: Conference Series 2 (2) (2019) $88-97$

\title{
Dampak Pemanfaatan Sarana Pendidikan (Oleh Guru) Terhadap Efektivitas Pembelajaran di SD Negeri Se-Gugus 1 Puspahiang
}

\author{
Dika Dianto, Riza Fatimah Zahrah, Agus Ahmad Wakih
}

Universitas Perjuangan Tasikmalaya

dikadyanto1@gmail.com

\section{Article History}

accepted 2/11/2019

approved 23/11/2019

published 31/12/2019

\begin{abstract}
In general, the purpose of this study is to analyze or test the hypothesis of whether or not the influence of the use of educational facilities (by teachers) on the effectiveness of learning in public elementary schools in Cluster 1 Puspahiang. The research method used in this study is a descriptive research method with a quantitative approach. The population in this study were 34 teachers spread across 8 public elementary schools in the Cluster 1 Puspahiang. Calculation analysis in this study uses the help of Microsoft Excel 2013 and SPSS 22.0 for windows. Correlation analysis between the utilization of educational infrastructure with the effectiveness of learning has a strong enough relationship with a correlation coefficient of 0.503. The magnitude of the effect of the utilization of educational infrastructure on the effectiveness of learning from the determination test results was $25.3 \%$, while $74.7 \%$ showed the effectiveness of learning was influenced by other factors not included in the discussion of this study. Significance calculation results obtained hargahitung price of 3.288, while ttabel with $\alpha=0.05$ is 2.036 means that th artinya $>$ itung is 3.288> 2.036 there is a significant relationship between variables $X$ and $Y$. The regression equation of the two variables namely $Y=41.889+0.161 X$ which means that the regression equation has the meaning that if the Utilization of Educational Facilities Means increases by one unit by 41,896 then the value of Learning Effectiveness $(Y)$ will increase by 0.161.
\end{abstract}

\section{Keyword : Utilization of Educational Facilities, Learning Effectiveness}

\begin{abstract}
Abstrak
Secara umum tujuan penelitian ini adalah untuk menganalisis atau menguji hipotesis ada atau tidaknya pengaruh pemanfaatan sarana pendidikan (oleh Guru) terhadap efektivitas pembelajaran di SD Negeri se-Gugus 1 Puspahiang. Metode penelitian yang digunakan dalam penelitian ini adalah metode penelitian desktiptif dengan pendekatan kuantitatif. Populasi dalam penelitian ini adalah 34 guru yang tersebar di 8 SD Negeri se-Gugus 1 Puspahiang. Analisis perhitungan dalam penelitian ini menggunakan bantuan program Microsoft Excel 2013 dan SPSS 22.0 for windows. Analisis korelasi antara pemanfaatan sarana prasarana pendidikan dengan efektivitas pembelajaran memiliki hubungan cukup kuat dengan nilai koefisien korelasi sebesar 0,503 . Besarnya pengaruh pemanfaatan sarana prasarana pendidikan terhadap efektivitas pembelajaran dari hasil uji determinasi sebesar $25,3 \%$, sedangkan $74,7 \%$ menunjukkan efektivitas pembelajara dipengaruhi oleh factor lain yang tidak termasuk dalam pembahasan penelitian ini. Hasil perhitungan signifikasi diperoleh harga thitung sebesar 3,288 , sedangkan ttabel dengan $\alpha=0,05$ adalah 2,036 artinya thitung $>$ ttabel yaitu 3,288>2,036 terdapat hubungan yang signifikan antara variabel $X$ dan $Y$. Adapun persamaan regresi dari kedua variabel yaitu $Y=41,896+0,161 X$ yang artinya persamaan regresi tersebut mempunyai arti bahwa jika Pemanfaatan Sarana Prasarana Pendidikan bertambah satu satuan sebesar 41,896 maka nilai Efektivitas Pembelajaran (Y) akan bertambah sebesar 0,161.

Kata Kunci: Pemanfaatan Sarana Pendidikan, Efektivitas Pembelajaran
\end{abstract}

Social, Humanities, and Education Studies (SHEs): Conference Series https://jurnal.uns.ac.id/shes

p-ISSN 2620-9284

e-ISSN 2620-9292 


\section{PENDAHULUAN}

Pendidikan merupakan suatu kegiatan yang universal dalam kehidupan manusia. Setiap bidang kehidupan di masyarakat terdapat proses pendidikan baik yang disengaja maupun tidak disengaja. Pada pendidikan normal, penyelenggara pendidikan tidak lepas dari tujuan pendidikan yang akan dicapai, hal ini tertuang dalam Undang-Undang Nomor 20 Tahun 2003 tentang system Pendidikan Nasional. Tujuan pendidikan merupakan tolak ukur dari keberhasilan penyelenggaraan pendidikan. Pada dasarnya pendidikan sangat penting dalam kehidupan sehari-hari dan tidak dapat dipisahkan dalam kehidupan pribadi, keluarga, masyarakat, maupun bangsa dan negara. Pendidikan merupakan proses pembentukan jiwa manusia yang memungkinkan manusia itu tumbuh dan berkembang sesuai dengan potensi kemampuan serta kemauan yang ada pada dirinya. Tujuan pendidikan tersebut dapat dicapai apabila terciptanya pendidikan yang bermutu, yaitu dapat dicapai melalui pembelajaran yang efektif. Menurut Oemar Hamalik (dalam Supardi 2014: 164) menjelaskan bahwa efektivitas proses pembelajaran adalah sebuah kombinasi yang terdiri dari unsur-unsur manusiawi, fasilitas, perlengkapan, serta prosedur yang dapat mempengaruhi tujuan pembelajaran.

Berbagai upaya bisa dilakukan untuk meningkatkan efektivitas pembelajaran dan meningkatkan sarana pendidikan, menjadi salah satu faktor yang dapat mempengaruhi peningkatan efektivitas pembelajaran. Dengan adanya pemanfaatan sarana pendidikan yang tepat, maka akan memperlancar penerimaan bahan pelajaran yang diberikan siswa dalam proses pembelajaran. Sesuai dengan tujuan dan fungsi sekolah sebagai lembaga pendidikan yang harus menciptakan kualitas lulusan yang baik melalui pembelajaran yang efektif, maka sekolah perlu memperhatikan kelengkapan dan ketersediaan sarana baik secara kualitas maupun kuantitas. Hal tersebut merupakan prasyarat yang harus dimiliki oleh sekolah di masa sekarang ini. Apabila suatu sekolah kurang memperhatikan fasilitas/sarana pendidikan, maka proses pembelajaran akan dirasa kurang efektif. Hal ini akan mengakibatkan prestasi belajar anak menjadi rendah.

Kondisi nyata penggunaan atau pemanfaatan sarana di SD Negeri Se-Gugus 1 Puspahiang menunjukkan bahwa beberapa fasilitas penunjang pembelajaran sudah cukup baik, namun pada pemeliharaan dan pemanfaatan sarana yang ada masih kurang terawat dan ditemukan beberapa kendala, seperti kurang nya pemamfaatan media pembelajaran yang dilakukan di sekolah. Apabila media pembelajaran tidak dapat digunakan secara maksimal, maka pembelajaran tidak akan efektif sehingga berpengaruh terhadap prestasi peserta didik.

\section{METODE}

Metode penelitian yang dapat digunakan metode deskriftip melalui pendekatan kuantitatif. Pendekatan kuantitatif ini digunakan untuk mengetahui berapa besar dari variabel Pemanfaatan Sarana Pendidikan (Oleh Guru) terhadap variabel Efektivitas Pembelajaran dengan cara mengukur dan menghitung apa yang menjadi indikatorindikator variabel penelitian melalui sistem perhitungan statistika. Populasi pada penelitian ini mencakup guru PNS dan Non PNS di SD Negeri Se-Gugus I Puspahiang Kabupaten Tasikmalaya yang berjumlah 8 SD Negeri dengan 50 orang Guru.

Pengambilan sampel dalam penelitian ini menggunakan teknik simple rundom sampling. Untuk menentukan berapa minimal sampel diketahui, dapat digunakan rumus Slovin yang dikutip dari Umar Husaen (2008: 65) sebagai berikut: 


$$
n=\frac{N}{1+\left(N X d^{2}\right)}
$$

Dimana: $\mathrm{n} \quad=$ Jumlah sampel

$\mathrm{N} \quad=$ Jumlah Populasi

$\mathrm{d}^{2} \quad=$ Presisi yang ditetapkan

Pemakaian rumus di atas mempunyai asumsi bahwa populasi berdistribusi normal dan data relatif banyak. Dari rumus di atas, dapat dihitung dengan jumlah populasi diketahui yaitu sebanyak guru dan ditentukan presisinya sebesar $10 \%$ maka hasil perhitungan besar sampelnya yaitu:

$$
\mathrm{n}=\frac{50}{1+\left(50 \times 10 \% 6^{2}\right)}=33,333333333
$$

Hasil dari perhitungan rumus di atas berjumlah 33,333333333 lalu dibulatkan menjadi minimal 34 orang yang akan dijadikan sebagai sampel. Teknik sampling yang peneliti gunakan adalah Proportional Random Sampling.

\begin{tabular}{|c|c|c|c|}
\hline NO & UNIT SEKOLAH & JUMLAH POPULASI $(\mathrm{Ni})$ & JUMLAH SAMPEL $\left(n_{i}\right)$ \\
\hline 1 & SDN LENGKONGSARI & 6 & $\mathrm{n}_{1}=\frac{6}{50} \times 34=4,08 \approx 4$ \\
\hline 2 & SDN BUKITDAGO & 7 & $\mathrm{n}_{2}=\frac{7}{50} \times 34=4,76 \approx 5$ \\
\hline 3 & SDN 1 PUSPAHIANG & 7 & $\mathrm{n}_{3}=\frac{7}{50} x 34=4,76 \approx 5$ \\
\hline 4 & SDN 2 PUSPAHIANG & 6 & $\mathrm{n}_{4}=\frac{6}{50} x 34=4,08 \approx 4$ \\
\hline 5 & SDN 4 PUSPAHIANG & 7 & $\mathrm{n}_{5}=\frac{7}{50} x 34=4,76 \approx 5$ \\
\hline 6 & SDN MUSTIKASARI & 6 & $\mathrm{n}_{6}=\frac{6}{50} x 34=4,08 \approx 4$ \\
\hline 7 & SDN BARULAKSANA & 6 & $\mathrm{n} 7=\frac{6}{50} \times 34=4,08 \approx 4$ \\
\hline 8 & SDN CIPATANGGA & 5 & $\mathrm{n}_{8}=\frac{5}{50} \times 34=3,4 \approx 3$ \\
\hline & TOTAL & $N=50$ & $\mathrm{n}=34$ \\
\hline
\end{tabular}

Tabel 1. Hasil Perhitungan Jumlah Sampel

Sumber data yang digunakan adalah sumber data primer. Sumber data primernya yaitu data data yang diperoleh dari wawancara, (kuisioner) angket, dan studi dokumentasi. Skala yang digunakan dalam penelitian ini adalah menggunakan skala Likert. 
4th National Seminar on Guidance and Counseling (SNBK 2019) and Workshop on

Pedagogical Theory and Practice (WTPP 2019)

SHEs: Conference Series 2 (2) (2019) $88-97$

Tabel 2. Skala Likert

\begin{tabular}{|c|c|c|}
\hline \multicolumn{2}{|c|}{ Alternatif Jawaban } \\
\hline Variabel X (Pemanfaatan Sarana Pendidikan) & Variabel Y & Bobot \\
(Efektivitas Pembelajaran) & \begin{tabular}{c} 
Nilai \\
\hline Selalu (SL)
\end{tabular} Selalu (SL) & 5 \\
\hline Sering (SR) & Sering (SR) & 4 \\
\hline Kadang-kadang (KD) & Kadang-kadang (KD) & 3 \\
\hline Jarang (JR) & Jarang (JR) & 2 \\
\hline Tidak Pernah (TP) & Tidak Pernah (TP) & 1 \\
\hline
\end{tabular}

Uji prasyarat dalam penelitian ini dilakukan melalui Uji normalitas adalah uji yang dilakukan dengan tujuan untuk menilai sebaran data pada sebuah kelompok data atau variabel, apakah sebaran data tersebut berdistribusi normal atau tidak, Dalam perhitungannya dengan menggunakan SPSS versi 20.0 for Windows.

Uji hipotesis penelitian Adapun langkah dalam uji hipotesis penelitian adalah sebagai berikut :

\section{Analisis kokoefisien korelasi}

Analisis korelasi dilakukan untuk mengetahui derajat hubungan antara Variabel Pemanfaatan Sarana Pendidikan dan Variabel Y Efektivitas Pembelajaran.

Untuk menginterpretasikan koefisien korelasi tersebut, maka peneliti menggunakan kriteria sebagai berikut:

Tabel 3. Harga Koefisien nilai $r$

\begin{tabular}{|c|c|}
\hline Interval Koefisien & Tingkat Hubungan \\
\hline $0,800-1,000$ & Sangat Kuat \\
\hline $0,600-0,799$ & Kuat \\
\hline $0,400-0,599$ & Cukup Kuat \\
\hline $0,200-0,399$ & Rendah \\
\hline $0,000-0,199$ & Sangat Rendah \\
\hline
\end{tabular}

Dalam perhitungannya dengan menggunakan SPSS versi 20.0 for Windows.

\section{Uji koefisien determinasi}

Uji koefisien determinasi digunakan untuk mengetahui besarnya pengaruh presentase kontribusi variabel independen (X) terhadap variabel dependen ( $Y$ ). Adapun perhitungan koefisien determinasi menggunakan SPSS 20.0 for Windows.

\section{Uji tingkat signifikan}

Uji tingkat signifikan dilakukan untuk mengetahui apakah hubungan yang ditemukan tersebut berlaku untuk seluruh populasi atau tidak Adapun perhitungan menggunakan SPSS 20.0 for Windows 4. Uji regresi linier sederhana

Regresi dalam penelitian berguna untuk meramalkan atau memprediksi variabel terikat (y) apabila variabel bebas $(\mathrm{X})$ diketahui. Regresi sederhana dapat dianalisis karena didasari hubungan fungsional atau hubungan sebab akibat (klausal) antara variabel bebas dengan variabel terikat (Bambang, 2013: 148). Dalam perhitungannya dengan menggunakan SPSS versi 20.0 for Windows. 


\section{HASIL DAN PEMBAHASAN}

\section{HASIL}

\section{Pemanfaatan Sarana Pendidikan (oleh guru)}

Pemanfaatan sarana pendidikan Bambang Warsita (2008:37) dilihat dari tindakan menggunakan metode dan model, bahan dan peralatan media untuk meningkatkan suasana belajar, di aplikasikaan dari dari hasil Wawancara yang dilakukan peneliti dengan salah seorang guru. Kemudian setelah melakukan studi pendahuluan dengan wawacara, peneliti menggunakan penyebaran angket tertutup, yaitu pertanyaan atau pernyataan telah memiliki alternatif jawaban (option) yang tinggal dipilih oleh responden. Angket disebarkan kepada 34 guru dengan banyak butir 29 item soal dari 8 SD Negeri se-Gugus 1 yang ada di Puspahiang.

Berdasarkan hasil perhitungan dapat diketahui bahwa secara umum rata-rata kecenderungan (Pemanfaatan Sarana Pendidikan (Oleh Guru) dalam penelitian ini adalah 4,54 dengan demikian, menunjukkan bahwa berada pada kategori sangat baik. Pemanfaatan sarana pedidikan dalam penelitian ini diuraikan menjadi empat indikator, yaitu identifikasi kebutuhan, penggunaan atau pemanfaatan, metode pemeliharaan dan perbaikan sarana .

Berikut grafik hasil dari perhtungan WMS setiap indikator (Pemanfaatan Sarana Pendidikan (oleh guru))

Gambar 1. Hasil dari Perhitungan WMS setiap Indikator Pemanfaatan Sarana

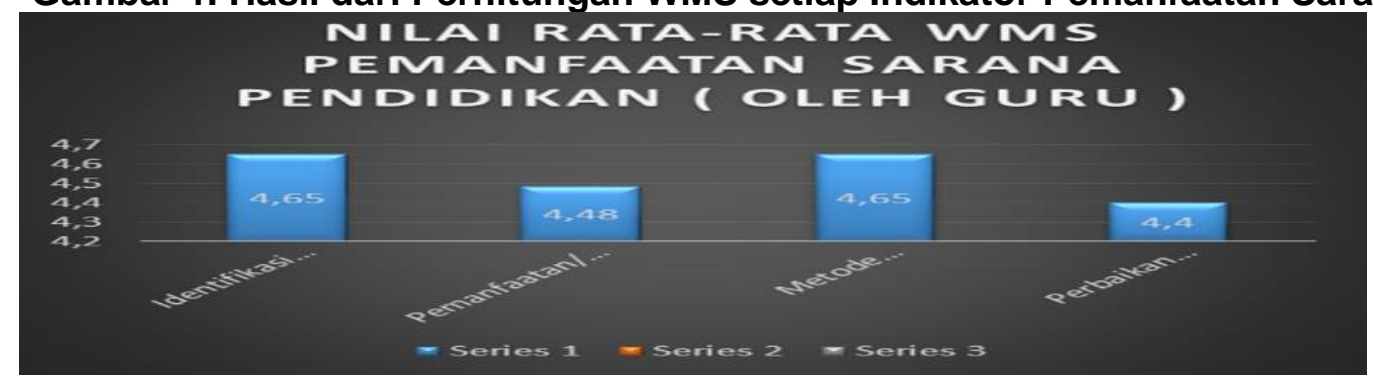

Berdasarkan gambar 1. Bahwa indicator identifikasi sebesar 4.65, pemanfaatan sebesar 4.48, metode sebesar 4.65 dan perbaikan sebesar 4.4.

\section{Efektivitas Pembelajaran}

Nilai Efektivitas Pembelajaran di peroleh dari hasil Wawancara yang dilakukan peneliti dengan salah seorang guru. Kemudian setelah melakukan studi pendahuluan dengan wawacara, peneliti mengguakan penyebaran angket tertutup, yaitu pertanyaan atau pernyataan telah memiliki alternatif jawaban (option) yang tinggal dipilih oleh responden. Angket disebarkan kepada 34 guru dengan banyak butir 33 item soal dari 8 SD Negeri se-Gugus 1 yang ada di Puspahiang.

Berdasarkan hasil perhitungan dapat diketahui bahwa secara umum kecenderungan skor Efektivitas Pembelajaran dalam penelitian ini adalah 4,61 dengan demikian, menunjukkan bahwa Efektivitas Pembelajaran berada pada kategori sangat baik. Efektivitas pembelajaran dalam penelitian ini diuraikan menjadi lima indikator yaitu sikap, kemampuan untuk memahami pengajaran, ketekunan, peluang, dan pengajara yang bermutu. Berikut grafik hasil dari perhitungan WMS setiap indikator Efektivitas Pembelajaran :

Gambar 2. Hasil dari Perhitungan WMS setiap indikator Efektivitas Pembelajaran 
4th National Seminar on Guidance and Counseling (SNBK 2019) and Workshop on Pedagogical Theory and Practice (WTPP 2019)

SHEs: Conference Series 2 (2) (2019) $88-97$

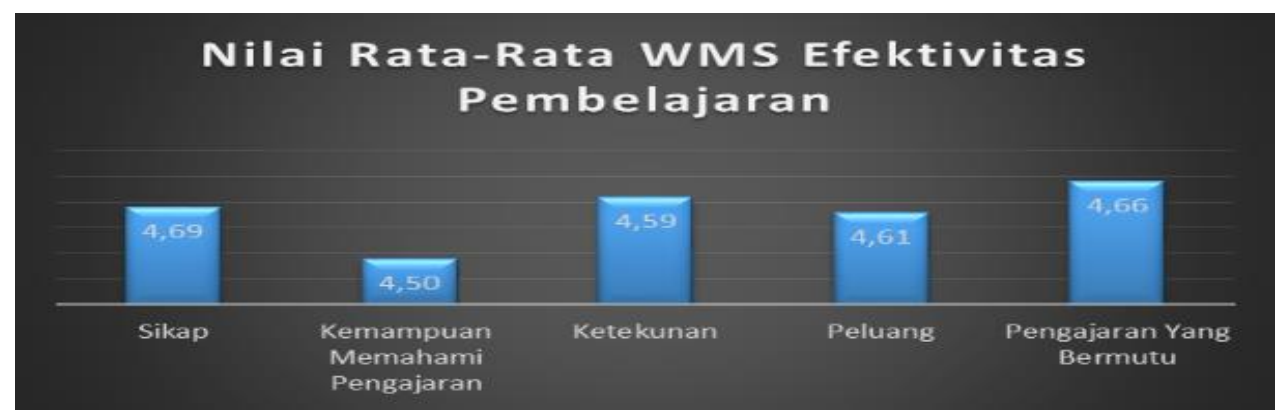

Berdasarkan gambar 2. Bahwa indicator efektifitas sikap memperoleh sebesar 4.69, indicator kemampuan memahami pengajaran sebesar 4.5, indicator ketekunan sebesar 4.59 , indicator peluang sebesar 4.61 dan indicator pengajaran yang bermutu 4.66.

\section{Analisis Data \\ a. Uji Normalitas data}

Tabel 3. Hasil Uji Normalitas Pemanfaatan sarana Pendidikan

One-Sample Kolmogorov-Smirnov Test

\begin{tabular}{|c|c|c|}
\hline & & $\begin{array}{c}\text { Pemanfaatan Sarana } \\
\text { Pendidikan ( Oleh Guru ) }\end{array}$ \\
\hline N & & 34 \\
\hline \multirow{3}{*}{ Normal Parameters ${ }^{\mathrm{a}, \mathrm{b}}$} & Mean & 49,91 \\
\hline & Std. Deviation & 9,398 \\
\hline & Absolute &, 129 \\
\hline \multirow[t]{2}{*}{ Most Extreme Differences } & Positive & ,074 \\
\hline & Negative &,- 129 \\
\hline Kolmogorov-Smirnov Z & & ,751 \\
\hline Asymp. Sig. (2-tailed) & & ,626 \\
\hline
\end{tabular}

Berdasarkan data dari tabel 3. diperoleh nilai Asympotic Significance 2-tailed sebesar 0,626 dengan jumlah responden sebanyak 34 responden. Hal tersebut menunjukkan 0,626 >0,05. Maka dapat disimpulkan bahwa Ho diterima, artinya tidak terdapat perbedaan distribusi data dengan distribusi normal. Sehingga data Variabel (Pemanfaatan Sarana Pendidikan (oleh guru)) dinyatakan berdistribusi normal.

Tabel 4. Hasil Uji Normalitas Efektivitas Pembelajaran

One-Sample Kolmogorov-Smirnov Test

\begin{tabular}{|ll|r|}
\hline & & Efektivitas Pembelajaran \\
\hline N & & \\
Normal Parameters ${ }^{\mathrm{a}, \mathrm{b}}$ & Mean & 34 \\
& Std. & 49,94 \\
& Deviation & 3,015 \\
Most Extreme Differences & Absolute &, 142 \\
Kolmogorov-Smirnov Z & Positive &, 089 \\
Asymp. Sig. (2-tailed) & Negative &,- 142 \\
\hline & &, 829 \\
\hline
\end{tabular}

a. Test distribution is Normat. 
Berdasarkan data tabel 4. diperoleh nilai Asympotic Significance 2-tailed sebesar 0,498 dengan jumlah responden sebanyak 34 responden. Hal tersebut menunjukkan 0,498 >0,05. Maka dapat disimpulkan bahwa Ho diterima, artinya tidak terdapat perbedaan distribusi data dengan distribusi normal. Sehingga data Variabel $Y$ (Efektivitas Pembelajaran) dinyatakan berdistribusi normal.

\section{b. Uji Hipotesis Penelitian}

Tabel 5. Uji Koefisien Korelasi

Correlations

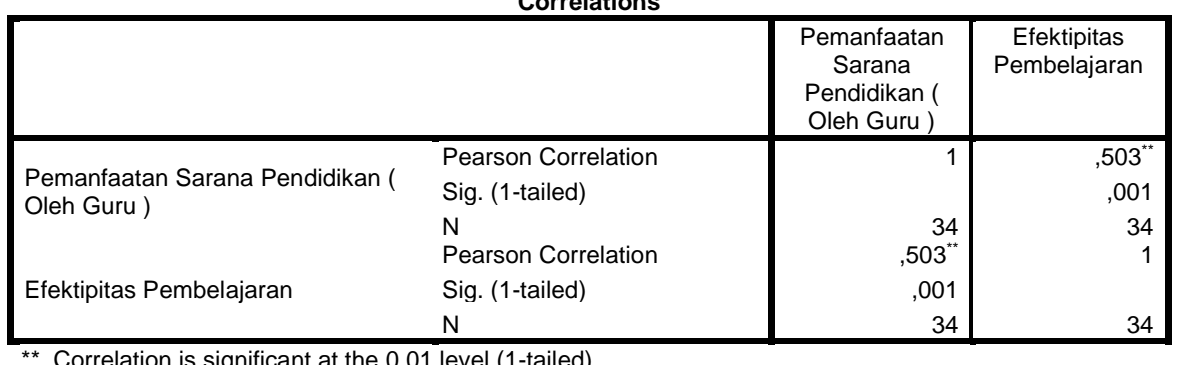

Berdasarkan data tabel 5. dapat diketahui bahwa nilai korelasi pada variabel (Pemanfaatan Sarana Pendidikan ( Oleh Guru) dan variabel (efektivitas Pembelajaran) adalah sebesar 0,503. Maka koefisien korelasi dengan nilai 0,503 berada pada interval cukup kuat, artinya tingkat korelasi antara variabel $x$ dan variabel y adalah cukup kuat. Hal ini dapat ditafsirkan bahwa hubungan antara Pemanfaatan Sarana Pendidikan dan Efektivitas Pembelajaran di SD se-Gugus 1 Puspahiang memiliki hubungan cukup kuat.

Tabel 6. Uji Korfisien Determinasi

Model Summaryb

\begin{tabular}{|c|c|c|c|c|c|c|c|c|c|}
\hline \multirow[t]{2}{*}{ Model } & \multirow[t]{2}{*}{$\mathrm{R}$} & \multirow{2}{*}{$\begin{array}{l}\mathrm{R} \\
\text { Squ } \\
\text { are }\end{array}$} & \multirow{2}{*}{$\begin{array}{c}\text { Adjuste } \\
\text { d R } \\
\text { Square }\end{array}$} & \multirow{2}{*}{$\begin{array}{l}\text { Std. Error } \\
\text { of the } \\
\text { Estimate }\end{array}$} & \multicolumn{5}{|c|}{ Change Statistics } \\
\hline & & & & & $\begin{array}{c}\mathrm{R} \\
\text { Square } \\
\text { Chang } \\
\mathrm{e}\end{array}$ & F Change & $\mathrm{df1}$ & $\mathrm{df2}$ & $\begin{array}{l}\text { Sig. F } \\
\text { Change }\end{array}$ \\
\hline 1 &, $503^{\mathrm{a}}$ & ,253 & ,229 & 2,64665 & ,253 & 10,811 & 1 & 32 &, 002 \\
\hline
\end{tabular}

a. Predictors: (Constant), Pemanfaatan Sarana Pendidikan ( Oleh Guru ))

Be buagandent Variable: Efektivitas Pembelajaran Tingkat hubungan antara Variabel (Pemanfaatan Sarana Pendidikan ( oleh Guru )) dengan variabel (Efektivitas Pembelajaran) adalah sebesar 25,3\%. Hal ini dapat disimpulkan bahwa Pemanfaatan Sarana Pendidikan (oleh guru) terhadap Efektivitas Pembelajaran berpengaruh sebesar $25,3 \%$. Selebihnya $74,7 \%$ dipengaruhi oleh faktor lain yang tidak termasuk dalam pembahasan penelitian ini.

Tabel 7.Uji Tingkat signifikan

Coefficients $^{a}$

\begin{tabular}{|c|c|c|c|c|c|}
\hline \multirow[t]{2}{*}{ Model } & \multicolumn{2}{|c|}{ Unstandardized Coefficients } & \multirow{2}{*}{$\begin{array}{c}\begin{array}{c}\text { Standardized } \\
\text { Coefficients }\end{array} \\
\text { Beta }\end{array}$} & \multirow[t]{2}{*}{$\mathrm{T}$} & \multirow[t]{2}{*}{ Sig. } \\
\hline & B & Std. Error & & & \\
\hline (Constant) & 41,896 & 2,489 & & 16,835 &, 000 \\
\hline $\begin{array}{l}\text { Pemanfaatan Sarana } \\
\text { Pendidikan ( Oleh Guru ) }\end{array}$ &, 161 &, 049 &, 503 & 3,288 &, 000 \\
\hline
\end{tabular}

Berdasarkan table 7 diperoleh hasil dari uji-t sebesar 3,288. Koefisien korelasi dianggap signifikan apabila terhitung $>$ tabel. Maka hasil yang diperoleh dari harga thitung adalah 3,288 , sedangkan harga ttabel dengan $(\mathrm{dk}=\mathrm{n}-2) \mathrm{dk}=34-2=32$, maka ttabel adalah 2,036 Hal ini dapat disimpulkan bahwa terdapat hubungan yang 
signifikan dan positif antara variabel X (Pemanfaatan Sarana Pendidikan ( oleh Guru ) ) dengan variabel $Y$ (Efektivitas Pembelajaran).

Tabel 8.Uji Linier Sederhana

Coefficients $^{\mathrm{a}}$

\begin{tabular}{|c|c|c|c|c|c|}
\hline \multirow[t]{2}{*}{ Model } & \multicolumn{2}{|c|}{ Unstandardized Coefficients } & \multirow{2}{*}{$\begin{array}{c}\begin{array}{c}\text { Standardized } \\
\text { Coefficients }\end{array} \\
\text { Beta }\end{array}$} & \multirow[t]{2}{*}{$\mathrm{T}$} & \multirow[t]{2}{*}{ Sig. } \\
\hline & B & Std. Error & & & \\
\hline (Constant) & 41,896 & 2,489 & & 16,835 & ,000 \\
\hline $\begin{array}{l}\text { Pemanfaatan Sarana } \\
\text { Pendidikan ( Oleh Guru ) }\end{array}$ & ,161 & ,049 & ,503 & 3,288 & ,000 \\
\hline
\end{tabular}

Berdasarkan table 8 . hasil perhitungan analisis regresi diatas, maka dapat diketahui bahwa nilai konstan (constant) sebesar 41,896 dan nilai beta sebesar 0,161 serta thitung sebesar 3,288 dan tingkat signifikasi 0,000. Dari tabel coefficients di atas maka diperoleh persamaan regresi sederhana dengan rumus $(\hat{Y}=a+b X)$ maka $\hat{Y}=41,896+0,161 \mathrm{X}$ yang artinya bahwa nilai regresi 0,161 menyatakan bahwa setiap penambahan satu poin Pemanfaatan Sarana Pendidikan, maka akan meningkat pula Efektivitas Pembelajaran sebesar 0,161. Hal ini dapat diartikan bahwa variabel $X$ mempunyai hubungan yang erat dengan variabel $Y$. begitupun dengan variabel $Y$ yang mempunyai ketergantungan terhadap variabel $X$ dengan arah perubahan positif. Sehingga hipotesis yang telah dirumuskan diterima, yaitu terdapat hubungan yang positif dan signifikan antara Pemanfaatan Sarana Pendidikan oleh Guru terhadap Efektivitas Pembelajaran di SD Negeri se-Gugus 1 Puspahiang.

\section{PEMBAHASAN}

\section{Pemanfaatan Sarana Pendidikan (oleh guru) di SD se-Gugus 1 Puspahiang}

Pada bagian ini, peneliti akan membahas hasil penelitian yang merupakan suatu kajian terhadap temuan yang diperoleh di lapangan dengan tujuan untuk menjawab rumusan masalah dalam penelitian ini, yaitu gambaran mengenai Dampak Pemanfaatan Sarana Pendidikan ( oleh Guru ) terhadap Efektivitas Pembelajaran di SD Negeri se-Gugus 1 Puspahiang. Berdasarkan perhitungan WMS dapat diketahui gambaran umum mengenai Pemanfaatan Sarana Pendidikan di SD se-Gugus 1 Puspahiang menunjukkan dalam kategori sangat baik dengan menggunakan perhitungan WMS sebesar 4,54. Hal tersebut dapat diartikan bahwa Guru di SD Negeri se-Gugus 1 Puspahiang sudah menggunakan atau memanfaatkan sarana dengan baik sesuai dengan mata pelajaran dan tujuan pendidikannya.

Pemanfaatan sarana pendidikan nampak pada empat indikator masuk dalam kategori sangat baik. Pemanfaatan sarana pendidikan dalam kategori sangat baik ini diharapkan dapat membantu dalam keberlangsungan proses pembelajaran, seperti dalam identifikasi kebutuhan sarana yang akan digunakan seperti pemilihan sumber belajar, media pembelajaran, dan alat peraga yang digunakan dalam proses pembelajaran sesuai dengan materi pembelajaran, perencanaan yang baik dalam menggunakan sarana belajar, penataan ruang belajar, dan penggunaan yang sesuai dengan petunjuk pemakaiannya. Dengan begitu diharapkan siswa dapat lebih memahami dan dapat mengikuti pembelajaran dengan lebih nyaman, sehingga pembelajaran dapat berlangsung dengan lebih efektif dan efisien. Diharapkan juga guru dan siswa dapat lebih bersemangat dalam melaksanakan kegiatan belajar mengajar sehingga tujuan pembelajaran dapat tercapai. Lebih jelasnya, akan terlihat dari perolehan rata-rata WMS setiap indikatpr mulai dari identifikasi kebutuhan sarana 
pendidikan (media pembelajaran, sumber belajar dan alat pembelajaran), penggunaan atau pemanfaatan sarana pendidikan, metode pemeliharaan sarana yang dilakukan dalam penggunaannya, dan juga perbaikan sarana pendidikan.

\section{Efektivitas Pembelajaran di SD Negeri se-Gugus 1 Puspahiang}

Berdasarkan hasil penelitian, dapat diketahui gambaran umum mengenai efektivitas pembelajaran di SD Negeri se-Gugus 1 Puspahiang masuk dalam kategori sangat baik dengan nilai perhitungan WMS sebesar 4,61. Hal tersebut dapat diartikan bahwa efektivitas pembelajaran di SD Negeri se-Gugus 1 Puspahiang sudah dalam kategori sangat baik.

Adapun indikator efektivitas pembelajaran memiliki skor tertinggi adalah sikap dengan skor perhitungan WMS sebesar 4,69 yaitu kategori sangat baik. Sedangkan indikator efektivitas pembelajaran terendah adalah kemampuan untuk memahami pengajaran sebesar 4,50 dengan kategori yang sama yaitu kategori sangat baik.

\section{Dampak Pemanfaatan Sarana Pendidikan (oleh Guru) Terhadap Efektivitas Pembelajaran SD Negeri se-Gugus 1 Puspahiang}

Berdasarkan hasil perhitungan WMS dengan bantuan program SPSS Versi 20.0 for Windows dan menggunakan rumus korelasi Pearson Product Moment, diperoleh harga koefisien korelasi (rxy) sebesar 0,503, harga korelasi tersebut dikonsultasikan dengan pedoman interpretasi koefisien korelasi nilai $r$ yaitu berada diantara koefisien korelasi interval 0,400 - 0,599. Dengan demikian, interpretasi terhadap koefisien korelasi adalah terdapat pengaruh cukup kuat antara variabel $X$ (Pemanfaatan Sarana Pendidikan (oleh Guru) dan variabel Y (Efektivitas Pembelajaran).

Selanjutnya, untuk mengetahui signifikansi korelasi antara variabel $X$ (Pemanfaatan Sarana Pendidikan (oleh guru)) dan variabel $Y$ (Efektivitas Pembelajaran) dengan membandingkan antara thitung $>$ ttabel. Hasil perhitungan diperoleh harga thitung sebesar 3,288 sedangkan ttabel dengan $\alpha=0,05$ uji satu arah dan dan $\mathrm{dk}=\mathrm{n}-2=34-2=32$, maka diperoleh ttabel sebesar 2,036, kaidah pengujiannya adalah jika thitung $>$ ttabel, maka dinyatakan signifikan. Dapat diartikan bahwa koefisien korelasi antara variabel $X$ (Pemanfaatan Sarana Pendidikan (oleh Guru) ) dan variabel Y (Efektivitas Pembelajaran) adalah signifikan, dengan melihat hasil perhitungan uji signifikan, maka perbandingannya menunjukkan bahwa 3,288 > 2,036, hal tersebut dapat diartikan bahwa koefisien korelasi antara Pemanfaatan Sarana Pendidikan (oleh guru) dengan Efektivitas Pembelajaran di SD Negeri seGugus 1 Puspahiang adalah signifikan, dan dapat digeneralisasikan atau berlaku untuk seluruh responden. Kemudian hubungan atau korelasi dalam penelitian unu dipertegas dengan adanya hasil perhitungan koefisien determinasi (KD) yang menunjukkan bahwa adanya pengaruh antara variabel $X$ (Pemanfaatan Sarana Pendidikan oleh guru ) dengan variabel Y (Efektivitas Pembelajaran) di SD se-Gugus 1 Puspahiang dengan perolehan harga koefisien korelasinya sebesar 25,3\%. Hal ini dapat diartikan bahwa tingkat Efektivitas Pembelajaran 25,3\% dipengaruhi oleh Pemanfaatan Sarana Pendidikan (oleh guru), selebihnya $74,7 \%$ dapat dipengaruhi oleh lingkungan belajar, kesiapan guru mengajar, pelaksanaan moving class, motivasi belajar, kinerja atau kompetensi guru, dan sebagainya.

Adapun tingkat hubungan fungsional antara variabel $X$ (Pemanfaatan Sarana Pendidikan (oleh guru)) dan variabel Y (Efektivitas Pembelajaran) diperoleh persamaan regresi $\hat{Y}=41,896+0,161 \mathrm{X}$. Dengan demikian, diketahui bahwa setiap ada perubahan pada satu unit variabel $X$ maka akan berpengaruh terhadap variabel $Y$ yaitu sebesar 0,161 , begitu pula dengan variabel $Y$ memiliki ketergantungan terhadap variabel $X$ dengan arah perubahan positif. Sehingga, hipotesis penelitian yang dirmuskan dapat diterima, yaituu terdapat pengaruh yang signifikan dari Pemanfaatan 
Sarana Pendidikan (oleh Guru) terhadap Efektivitas Pembelajaran di SD Negeri seGugus 1 Puspahiang.

Hal tersebut sejalan dengan teori yang dikemukakan oleh Supardi (2013:165) bahwa efektivitas pembelajaran adalah kombinasi yang tersusun meliputi unsur-unsur manusiawi, material, fasilitas, perlengkapan, dan prosedur diarahkan untuk mengubah perilaku siswa kearah yang positif dan lebih sesuai dengan potensi dan perbedaan yang dimiliki siswa untuk mencapai tujuan pembelajaran yang ditetapkan.

\section{SIMPULAN}

Berdasarkan hasil dan pembahasan yang telah diuraikan dapat ditarik kesimpulan bahwa:

1. Gambaran mengenai Pemanfaatan Sarana Pendidikan (oleh Guru) di SD Negeri se-Gugus 1 Puspahiang berada dalam kategori sangat baik. Hal ini menunjukkan bahwa dalam penggunaan fasilitas belajar yang dilakukan oleh guru dimulai dari identifikasi kebutuhan, penggunaannya, metode pemeliharaan hingga perbaikan sudah dilakukan sebagaimana mestinya.

2. Gambaran Efektivitas Pembelajaran di SD Negeri se-Gugus 1 Puspahiang berada pada kategori sangat baik. Efektivitas pembelajaran menjadi tolok ukur terciptanya tujuan pembelajaran dengan hasil yang didapat. Efektivitas pembelajaran yang dimaksud dalam penelitian ini diukur melalui lima indikator diantaranya: sikap, kemampuan untuk memahami pengajaran, ketekunan, peluang, dan pengajaran yang bermutu.

\section{DAFTAR PUSTAKA}

Bafadal, Ibrahim. (2004). Manajemen Perlengkapan Sekolah: teori dan Aplikasinya. Jakarta: PT Bumi Aksara

Komara, Endang. (2014). Belajar dan Pembelajaran Interaktif. Bandung: Refika Aditama.

Mulyasa, E. (2004). Manajemen Berbasis Sekolah. Bandung: PT Remaja Rosdakarya.

Mulyasa, E. (2009). Implementasi KTSP Kemandirian Guru dan Kepala Sekolah. Jakarta: PT Bumi Aksara.

Supardi. (2013). Sekolah Efektif (Konsep Dasar dan Praktiknya). Jakarta: PT Raja Grafindo Persada

Supriadi. (2015). Pemanfaatan Sumber Belajar Dalam Proses Pembelajaran. Lantanida Journal, Volume 3, Nomor 2, 2015

Suryosubroto, (2002). Proses Belajar Mengajar di Sekolah. Jakarta: PT Rineka Cipta

Undang-Undang No 20 Tahun 2003 Tentang Sistem Pendidikan Nasional

Warsita, Bambang. (2008) Teknologi Pembelajaran :Landasan dan Aplikasinya. Jakarta: Rineka

Warsita, Bambang. (2013) Teknologi Pembelajaran :Landasan dan Aplikasinya. Jakarta: Rineka 